\title{
Organic matter management for sustainable productivity of corn-groundnut cropping pattern on acid upland soils
}

\author{
Agus Supriyo*, Sri Minarsih, and Budi Winarto \\ Assessment Institute for Agricultural Technology of Central Java, Ministry of Agriculture, Jl. \\ Soekarno-Hatta Km. 26 No. 10, Bergas, Central Java, 50552, Indonesia
}

\begin{abstract}
This study aims to conduct the organic management that sustain productivity of corn-groundnut sequential cropping on acid upland soil in South Kalimantan, Indonesia. Tanah Laut Regency is the target area for this conservation farming system. Furthermore, these areas havebeen identified potentially for food crop development The experiment was conducted Bumi Asih villages, Panyipatan sub district, Tanah Laut, South Kalimantan provinces. In 1994/1995 WS until 1995 DS. These area as a ultisol soil type and transmgiration areas. Randomized Complete Block Desgind (RCBD) with four replication, and plot size $10 \mathrm{~m}$ x $20 \mathrm{~m}$. There were Six treatment consisted of O1(No Farm Yard Manure/FYM), organic matter remains

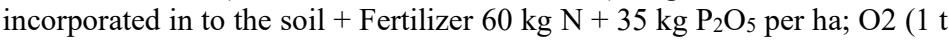
FYM organic matter remains incorporated in to the soil $+120 \mathrm{~kg} \mathrm{~N}+70 \mathrm{~kg}$ $\mathrm{P}_{2} \mathrm{O}_{5} / \mathrm{ha}$ ); $\mathrm{O} 3$ (All organic matter remains incorporaed in to the soil $+2,5 \mathrm{t}$ FYM/ha); O4 (as Treatment O3 + 5 t FYM/ha); O5 (as treatment O3 + $10 \mathrm{t}$ FYM/ha) and O6 (as treatment O3 + 20 t FYM/ha). Corn cv Arjuna was planted with row spacing $200 \mathrm{~cm} \times 20 \mathrm{~cm}$; and intercrops with Groundnut cv Pelanduk with row spacing $25 \mathrm{~cm} \times 20 \mathrm{~cm}$ during two seasons planting. Data were colect i.e some physical soil properties such as soil moisture; soil hardness; some chemical soil properties such as soil $\mathrm{pH}$, Org-C; plant nutrient such plant nutrient content such as leaf of $\mathrm{N} ; \mathrm{P} ; \mathrm{Ca}$ and $\mathrm{Mg}$ contents.. Growth parameter i.e shoot dry weight and yield of corn and groundnut. Data colected were analyzed by Variant analyzis. Diferently among treatment were analyzed by DMRT.0.05.. ...The results showed that the increase ins oil $\mathrm{pH}$ due to highC-organd some nutrient contents such as $\mathrm{N}, \mathrm{P}$, $\mathrm{Ca}$ and $\mathrm{P}$ inleaf of corn were significantly affected during the last seasons by organic amendment. In terms of cultivation, organic matter increased the infestation of weeds.. The organic management with the highest application (20 tonnes.ha ${ }^{-1} \mathrm{FYM}$ ) in every season yielded up to four - five times for corn and $0.65-1.28$ for groundnut compared to control/farmer practices $(1.175 \mathrm{t}$ dry seed/ha).
\end{abstract}

\section{Introduction}

Indonesia is located in a wet tropical area with a low soil organic matter $(<2 \%)$ and acidic

\footnotetext{
* Corresponding author: agssupriyo@yahoo.com
} 
$\mathrm{pH}$. It has a problematic mineral soil due to the high rate of decomposition of organic matter and leaching of nutrients. that approximately $73 \%$ of agricultural land has a soil organic $\mathrm{C}$ content of $<2.0 \%$. [9]The potential for acid dry land with the Podsolik Merah Kuning(PMK) soil type is estimated to be 22.5 million hectares. These are scattered in the regions of Kalimantan, Sumatra, Sulawesi, and Papua [7]. Part of this land has been cultivated for agricultural expansion, particularly through the transmigration program. Potentially, the soil has chemical and physical constraints that do not disturb the forest ecosystems because of a balanced nutrient cycle. PMK's fertility issues become serious once the land is cultivated, especially for seasonal crops. Furthermore, land productivity decreases drastically after the first cropping due to reduced organic matter content as well as erosion and the high rate of weathering. This increases the acidic and the AI saturation of the soil. The management on dry land at the transmigration site of Kuamang Kuning, Jambi,7)has been able to prove this [12;3].Furthermore, similar result has also been reported by [3 ]]in Columbia, that the production and soil fertility steadily decreased on dry land cultivated for rice, corn, and soybean for 4 consecutive years without fertilization and liming.

Acid dry land has low soil $\mathrm{pH}$, cation exchange capacity (CEC), base saturation (BS) and low organic C. Also, it has high aluminum content (Al saturation), $\mathrm{P}$ embeds, Fe and $\mathrm{Mn}$ content close to plant toxic limits, sensitivity to erosion and poor biotic elements [2]. The high rainfall in some parts causes a high level of nutrient leaching out of the soil especially the bases. In the clay and humus adsorption complex only $\mathrm{H}$ and $\mathrm{Al}$ ions are left. Therefore, the soil reacts with low base and produces high Al saturation $[9 ; 10 ; ; 8]$.

The podsolic soil fertility is highly dependent on the organic matter content which is very unstable and decreases rapidly after land clearing. This situation has long been proven by shifting cultivators, and results in a decreased buffering capacity against water and fertilizers. Therefore, the plants experience drought and a reduced fertilization efficiency.Efforts to manage organic matter appropriately are the goal of acid dryland agricultural cultivation technology. In addition, utilization of organic matter or compost increase plant productivity and improve e some chemical properties of dry acid soil.. The goals of this experiments were studied to (a) organic matter management on improves the physical and chemical properties of acid dry soil and (b) on yield of the corn-groundnut intercropping pattern in acid dry soil.

\section{Methodology}

The experiment was conducted Bumi Asih villages, Panyipatan sub district, Tanah Laut, South Kalimantan provinces. In 1994/1995 WS until 1995 DS. These area as a ultisol soil type and transmgiration areas. Randomized Complete Block Desgind (RCBD) with four replication, and plot size $10 \mathrm{~m}$ x $20 \mathrm{~m}$. There were Six treatment consisted of O1(No Farm Yard Manure/FYM), organic matter remains incorporated in to the soil + Fertilizer $60 \mathrm{~kg} \mathrm{~N}$ $+35 \mathrm{~kg} \mathrm{P} \mathrm{P}_{2} \mathrm{O}_{5}$ per ha; $\mathrm{O} 2$ ( $1 \mathrm{t} \mathrm{FYM}$ organic matter remains incorporated in to the soil +120 $\mathrm{kg} \mathrm{N}+70 \mathrm{~kg} \mathrm{P}_{2} \mathrm{O}_{5} / \mathrm{ha}$ ); $\mathrm{O} 3$ (All organic matter remains incorporaed in to the soil $+2,5 \mathrm{t}$ FYM/ha); O4 (as Treatment O3 + 5 t FYM/ha); O5 (as treatment O3 + 10 t FYM/ha) and O6 (as treatment $\mathrm{O} 3+20 \mathrm{t} \mathrm{FYM/ha).} \mathrm{Corn} \mathrm{cv} \mathrm{Arjuna} \mathrm{was} \mathrm{planted} \mathrm{with} \mathrm{row} \mathrm{spacing} 200 \mathrm{~cm} \mathrm{x}$ $20 \mathrm{~cm}$; and intercrops with Groundnut cv Pelanduk with row spacing $25 \mathrm{~cm}$ x $20 \mathrm{~cm}$ during two seasons planting. Data were colect i.e some physical soil properties such as soil moisture; soil hardness; some chemical soil properties such as soil $\mathrm{pH}$, Org-C; plant nutrient such plant nutrient content such as leaf of N; P; Ca and Mg contents.. Growth parameter i.e shoot dry 
weight and yield of corn and groundnut. Data colected were analyzed by Variant analyzis. Diferently among treatment were analyzed by DMRT. 0.05

\section{Results and discussion}

\subsection{The Role of Organic Matter as in Improving SoilFertility}

Soil consists of living system that are processed into different types of fertilizer for plants. The main regulator (key to the process) is soil organic matter which acts as a buffer and maintains a balanced supply of nutrients. Furthermore, low organic matter content reduces the buffering capacity and fertilizer efficiency of the soil since they are lost in the root environment [7]. Most of the acid soils are low in organic content, especially when the residue is transported out or burned.

The productivity of dry acid soils results in low crops residual biomass. Even though the remaining harvest is returned to the soil, it is still not enough to compensate the decline in organic matter. It decreases rapidly, especially when the rest of the harvest is burned. Therefore, it is necessary to add organic material to the remaining harvest, such as using manure or compost of high input.

The application improves the physical, chemical, and biological properties of the soil [8]. Furthermore, the organic fertilizers derived from manure and remaining organic matter (existing weeds) improve some of the physical properties of the soil. It increases the soil moisture and decreases hardness below the tillage (Table 1). This is in line with the results, which was stated that the land reclamation of Ultisol; with green manure (Flemingia congesta $s p$ ) of 20-30 t/ ha and $0.5 \mathrm{t}$ of lime/ha increase soil $\mathrm{pH}$, organic matter content, P-tsd elements, and CEC as well as reduce $\mathrm{Al}$ saturation $[7 ; 12 ; 13]$.

Table 2 showed that the management of soil organic matter in Ultisol soil, Bumi Asih, Panyipatan Subdistrict, Tanah Laut Regency, South Kalimantan at a rate of $10 \mathrm{t} \mathrm{FYM/ha}$ increased the $\mathrm{pH}$ of $\mathrm{H}_{2} \mathrm{O}$ from 4.19 to 4.33 after the fourth planting season. In these areas were dominated by cropping pattern rice-palawija-palawija in a year [4; 5].

The increase in $\mathrm{pH}$ was due to the application of manure to the $\mathrm{Al}$ ion in the soil traps. Furthermore, the organic matter content $(0-10 \mathrm{~cm})$ became reduced compared to the initial after application. This was observed from planting season (PS1) to (PS) IV in each treatment. This indicates that the mineralization process is high and fast due to high relative humidity and heat.

The $\mathrm{N}$ nutrient content of corn plants increased with the provision of organic matter from $1.14 \%$ to $1.17-1.47 \%$. However, the $\mathrm{N}$ content was still below the adequacy level between $3.5 \%-4.5 \%$ [9] and the $\mathrm{P}$ content of corn plant leaves ranged from 0.26 to $0.30 \%$. Meanwhile, the concentration of plant Ca elements in all organic matter treatments was below the sufficient level $(0.11 \%-0.15 \%)$. The adequacy value was between $1.25 \%-2.00 \%$ and the $\mathrm{Mg}$ content was not sufficient (Table 2). 
Table 1. Organic management on soil moisture content and soil hardness of acid upland soil of Bumi Asih, Tanah Laut Regency, South Kalimantan

\begin{tabular}{|c|c|c|c|c|c|c|}
\hline \multirow{2}{*}{ Parameters } & \multicolumn{6}{|c|}{ Treatments } \\
\hline & $\mathrm{O} 1$ & $\mathrm{O} 2$ & $\mathrm{O} 3$ & $\mathrm{O} 4$ & O5 & O6 \\
\hline & \multicolumn{6}{|c|}{ 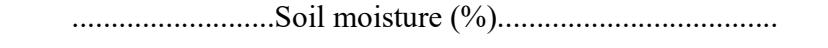 } \\
\hline a) $\mathrm{pF}: 2,00$ & 31.10 & 40.20 & 35.70 & 33.70 & 45.60 & 42.20 \\
\hline $\mathrm{pF}: 2,54$ & 27.70 & 38.40 & 32.70 & 27.70 & 37.20 & 36.00 \\
\hline $\mathrm{pF}: 3,00$ & 25.50 & 36.10 & 30.30 & 26.00 & 35.00 & 33.15 \\
\hline $\mathrm{pF}: 4,20$ & 19.70 & 25.50 & 24.70 & 23.10 & 26.40 & 31.60 \\
\hline b) $\mathrm{pF}: 2,00$ & 31.60 & 40.25 & 35.85 & 33.96 & 47.10 & 43.45 \\
\hline $\mathrm{pF}: 2,54$ & 28.10 & 37.65 & 22.21 & 31.25 & 38.10 & 38.20 \\
\hline $\mathrm{pF}: 3,00$ & 26.45 & 35.86 & 31.74 & 27.65 & 36.24 & 35.22 \\
\hline $\mathrm{pF}: 4,20$ & 20.43 & 27.95 & 25.20 & 24.32 & 27.65 & 33.45 \\
\hline Deep of soil profile & \multicolumn{6}{|c|}{ 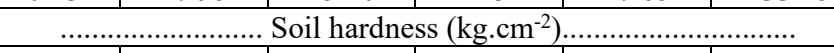 } \\
\hline a) $0-10 \mathrm{~cm}$ & 5.80 & 4.40 & 4.60 & 5.00 & 4.40 & 4.10 \\
\hline $10-20 \mathrm{~cm}$ & 10.60 & 12.30 & 18.50 & 18.65 & 17.00 & 15.00 \\
\hline b) $\quad 0-10 \mathrm{~cm}$ & 4.15 & 4.44 & 4.68 & 5.20 & 4.85 & 4.92 \\
\hline $10-20 \mathrm{~cm}$ & 10.52 & 12.24 & 19.14 & 18.76 & 17.22 & 15.46 \\
\hline
\end{tabular}

*)O1= No FYM, org. matter remains incorporated in to the soil, + fertilized $\left(60 \mathrm{~N}+35 \mathrm{P}_{2} \mathrm{O}_{5}\right) \mathrm{kg} / \mathrm{ha}$. $\mathrm{O} 2=+1 \mathrm{t} F Y M$, org matter remains incorporated in to the soil, + fertilized $\left(120 \mathrm{~N}+70 \mathrm{P}_{2} \mathrm{O}_{5}\right) \mathrm{kg} / \mathrm{ha}$.

$\mathrm{O} 3=\mathrm{All}$ organic matter remains incorporated in to the soil, $+2,5 \mathrm{t} \mathrm{FYM} / \mathrm{ha}$.

$\mathrm{O} 4=$ Treatment $3+5 \mathrm{t} \mathrm{FYM} / \mathrm{ha}$. O5=Treatment $3+10$ t FYM/ha. O6= Treatment $3+20$ t FYM/ha a) before first season planting, b) after $4^{\text {th }}$ seasons planting

Sources : $[14 ; 15]$.

Table 2. Organic management on several soil chemical properties $(0-10 \mathrm{~cm})$ and plant $\mathrm{N}$, $\mathrm{P}, \mathrm{K}, \mathrm{Ca}, \mathrm{Mg}$ content at Bumi Asih, Tanah Laut Regency, South Kalimantan

\begin{tabular}{|l|c|c|c|c|c|c|}
\hline \multirow{2}{*}{\multicolumn{1}{|c|}{ Parameters }} & \multicolumn{7}{|c|}{ Treatments $^{*}$} \\
\cline { 2 - 7 } & $\mathrm{O} 1$ & $\mathrm{O} 2$ & $\mathrm{O} 3$ & $\mathrm{O} 4$ & O5 & O6 \\
\hline $\mathrm{pH}\left(\mathrm{H}_{2} \mathrm{O}\right)$ a) & 4.04 & 4.19 & 4.27 & 4.31 & 4.33 & 4.31 \\
\hline $\left.\mathrm{pH}\left(\mathrm{H}_{2} \mathrm{O}\right) \mathrm{b}\right)$ & 4.08 & 4.21 & 4.32 & 4.45 & 4.45 & 4.39 \\
\hline Org-C(\%) a) & 2.12 & 2.14 & 2.23 & 2.35 & 2.53 & 2.46 \\
\hline Org-C(\%) b) & 2.10 & 2.12 & 2.18 & 2.30 & 2.38 & 2.28 \\
\hline Plant-Ncontent (\%) & 1,14 & 1,47 & 1,17 & 1,24 & 1,29 & 1,45 \\
\hline Plant-P content(\%) & 0,18 & 0,18 & 0,14 & 0,18 & 0,19 & 0,27 \\
\hline Plant-Ca cont (\%) & 0,14 & 0,15 & 0,11 & 0,14 & 0,14 & 0,13 \\
\hline Plant-Mg content (\%) & 0,25 & 0,29 & 0,23 & 0,23 & 0,22 & 0,19 \\
\hline
\end{tabular}

*) Noted same as Table 1. a) before first seasons planting, b) after fourth seasons planting.

\subsection{Role of Organic Materials on Growth and Yields}

The productivity of dry acid soils which are generally low also results in reduced crops residual biomass. Even when the remaining harvest is returned to the soil, it is still not enough to compensate for the decline in organic matter which is decreasing rapidly. Therefore, it is necessary to add organic materials to the remaining harvest, such as using manure or compost. 
The application increased the shoot and crown dry weight of the vegetative phase of the corn plant as well as the corn cobs, and dry peanut pods before harvest (Table 3 and Table 4). Furthermore, corn shoot dry weight at 5 WAP (5.79 g/plant) on MH 1995/1996 was greater than in MH 1995/1996 (3.53 g/plant). This is because the organic material has a ratio of $\mathrm{C} / \mathrm{N}=21<$ compared to that of $\mathrm{MH} 1995 / 1996(\mathrm{C} / \mathrm{N}=28)$. The $\mathrm{C} / \mathrm{N}$ ratio: 21 is close to ideal conditions $(\mathrm{C} / \mathrm{N}: 10-20)$ since the weathering process in the early growth phase is faster and the nutrients formed quickly are available and absorbed by the plant roots for growth.

Organic matter dosage (10 t - $20 \mathrm{t}$ manure/ha) increased the weight of corn cobs and groundnut pods in both growing seasons (GS) but was inconsistent, and this is related to the high intensity of rainfall. During the 1994/1995 WS, the total intensity of rain was $901 \mathrm{~mm}$, while in 1995/1996 WS it was 1,096 mm. According [4], the need for water consumption for corn during the planting season ranges from $350-400 \mathrm{~mm}$. The excessive rainfall intensity causes the effect of giving organic matter between treatments less obvious. This may result in high runoff and decreased fertilization efficiency.

Table 3. Organic matter management on shoot dry weight and yield of Corn-groundnut sequential cropping on acid upland soil at Bumi Asih, South Kalimantan.

\begin{tabular}{|c|c|c|c|c|c|c|}
\hline \multirow{2}{*}{$\begin{array}{l}\text { Treat- } \\
\text { ments* }\end{array}$} & \multicolumn{3}{|c|}{ Corn (1994/1995 WS) } & \multicolumn{3}{|c|}{ Groundnuts (1995 DS) } \\
\hline & Shoot $^{+}(\mathrm{g})$ & $\begin{array}{c}\text { Shoot }^{++} \\
\left(\text {t.ha }^{-1}\right)\end{array}$ & $\begin{array}{l}\text { Kernel } \\
\left(\text { t.ha }^{-1}\right)\end{array}$ & Shoot $+(g)$ & Shoot $++(g)$ & Pods $\left(\right.$ t.ha $\left.{ }^{-1}\right)$ \\
\hline $\mathrm{O} 1$ & $1,390 \mathrm{a} * *$ & $1,560 a^{* *}$ & $1,290 a^{* *}$ & $2,420 \mathrm{a} * *$ & $5,840 \mathrm{a}^{* *}$ & $2,420 a^{* *}$ \\
\hline $\mathrm{O} 2$ & $1,360 \mathrm{a}$ & $1,610 \mathrm{a}$ & $1,760 \mathrm{ab}$ & $2,780 \mathrm{a}$ & $6,280 \mathrm{ab}$ & $2,510 \mathrm{a}$ \\
\hline $\mathrm{O} 3$ & $1,740 \mathrm{a}$ & $1,930 \mathrm{ab}$ & $2,030 \mathrm{ab}$ & $3,010 \mathrm{a}$ & $6,020 \mathrm{a}$ & $2,640 \mathrm{a}$ \\
\hline $\mathrm{O} 4$ & $2,860 \mathrm{~b}$ & $2.710 \mathrm{~b}$ & $2,470 \mathrm{~b}$ & $2,660 \mathrm{a}$ & $6,000 \mathrm{a}$ & $3,460 \mathrm{~b}$ \\
\hline O5 & $5,140 \mathrm{c}$ & $6,160 \quad \mathrm{c}$ & $5,470 \quad \mathrm{c}$ & $5,410 \mathrm{~b}$ & $7,620 \mathrm{~b}$ & $3,810 \mathrm{bc}$ \\
\hline O6 & $8,480 \mathrm{~d}$ & $10,160 \mathrm{~d}$ & $8,060 \quad \mathrm{~d}$ & $6,700 \mathrm{c}$ & $7.340 \mathrm{ab}$ & $4,100 \mathrm{c}$ \\
\hline Aver & 3,530 & 4,020 & 3,510 & 3,830 & 6,520 & 3,270 \\
\hline
\end{tabular}

Note:*:Same as table $1,+$ ) Vegetatif phase.++) Harvest phase.**) Value followed by same note no different by DMRT, 05 Sources : $[14 ; 15]$

Table 4.Organic management on shoot dry weight and yield of sequential cropping Corn-Groundnut on acid upland soil in Bumi Asih, , South Kalimantan.

\begin{tabular}{|c|c|c|c|c|c|c|}
\hline \multirow[b]{2}{*}{$\begin{array}{l}\text { Treat- } \\
\text { ments* }\end{array}$} & \multicolumn{3}{|c|}{ Corn (1995/1996 WS) } & \multicolumn{3}{|c|}{ Groundnut (1996 DS) } \\
\hline & $\begin{array}{c}\text { Shoot dw } \\
(\mathrm{g})\end{array}$ & $\begin{array}{l}\text { Shoot dw }{ }^{++} \\
(\mathrm{t} / \mathrm{ha})\end{array}$ & $\begin{array}{c}\text { Kernel } \\
(\mathrm{t} / \mathrm{ha})\end{array}$ & $\begin{array}{c}\text { Shoot dw }{ }^{+} \\
(\mathrm{g})\end{array}$ & $\begin{array}{c}\text { Shoot dw } w^{++} \\
(\mathrm{g})\end{array}$ & Pods (t/ha) \\
\hline O1 & $4,050 \mathrm{a} * *$ & $0,420 a^{* *}$ & $0,500 a^{* *}$ & $2,720 a^{* *}$ & $1,710 a^{* *}$ & $1,220 \mathrm{a}^{*}$ \\
\hline $\mathrm{O} 2$ & $5,650 \mathrm{ab}$ & $0,950 \mathrm{a}$ & $1,610 b c$ & $3,010 \mathrm{ab}$ & $3,080 \mathrm{bc}$ & $1,240 \mathrm{a}$ \\
\hline $\mathrm{O} 3$ & $5,950 \mathrm{~b}$ & $0,600 \mathrm{a}$ & $0,720 \mathrm{ab}$ & $3,310 \mathrm{~b}$ & $2,680 \mathrm{ab}$ & $1,680 \mathrm{~b}$ \\
\hline $\mathrm{O} 4$ & $3,860 \mathrm{ab}$ & $0.730 \mathrm{a}$ & $0,730 \mathrm{ab}$ & $4,580 \quad \mathrm{c}$ & $2.280 \mathrm{a}$ & $1,570 \mathrm{ab}$ \\
\hline $\mathrm{O} 5$ & $6,140 \mathrm{c}$ & $1,760 \mathrm{a}$ & $2,120 \mathrm{~cd}$ & $5,780 \mathrm{~d}$ & $4,100 \mathrm{c}$ & $2,150 \mathrm{c}$ \\
\hline O6 & $8,690 \mathrm{~d}$ & $2,250 \mathrm{~b}$ & $3,140 \mathrm{~d}$ & 6,940 e & $3.710 \mathrm{c}$ & $2,590 \mathrm{c}$ \\
\hline Avrg & 5.790 & 1,080 & 1.470 & 4.400 & 2.920 & 1.740 \\
\hline
\end{tabular}

Notes:*) Same as Table $1 .{ }^{+}$Vegetative phase ${ }^{++}$Harvest phase.. ${ }^{* *}$ ) Values followed by same note no different by DMRT,05. Sources : [14; 15]

The analysis during the two rainy seasons showed that the application of organic fertilizers increased the average yield on $1994 / 1995$ WS by $2.16 \mathrm{t}$ dry shells, higher than $1995 / 1996$ WS which was 1.10 dry shelled t/ha (Table 5). This is due to the intensity of rainfall at the beginning of plant growth (vegetative phase) in November 1994/1995 of 130 $\mathrm{mm}$. Meanwhile, the intensity of rainfall in December 1995/1996 WS: $312 \mathrm{~mm}$, resulted in high surface water runoff and lowering fertilization efficiency. Total rainfall on 1995/1996 
WS during one growing season was $1,096 \mathrm{~mm}$. The water consumption for corn during the growing season was between $350-400 \mathrm{~mm}$ [4]. The difference in the dosage of organic fertilizers in the two growing seasons became evident between the rate of $2.5 \mathrm{t}-20 \mathrm{t} / \mathrm{ha}$. The highest yield increase was at the rate of $20 \mathrm{t} \mathrm{FYM/ha} \mathrm{(O6)} \mathrm{in} \mathrm{the} \mathrm{two} \mathrm{growing} \mathrm{seasons.} \mathrm{It} \mathrm{was}$ 4, 1, and 5.12 times above the control (O1) in the rainy season 19941995 and MH 1994/1995 ( Table 5).

The two dry season's analysis results (MK 1995 and MK 1996) for groundnut plants showed thatfarm yard manure (FYM) increased yields higher in MK 1995 than in MK 1996. Furthermore, the yields in MK 1995 were 1,930 t seeds/ha and were 1,300 t of seeds/ha in MK 1996 (Table 5). This is because the intensity of rainfall in the flowering phase of May 1995 (MK 1995) was $110 \mathrm{~mm}$, and was $204 \mathrm{~mm}$ in May 1996 (MK 1996). This high intensity of rainfall resulted in reduced pods production from flowers. The total intensity of rainfall during MK 1995 (540 mm) was lower than in MK 1996 which was $725 \mathrm{~mm}$. The water consumption for normal groundnut plants for $1 \mathrm{MT}$ is $280-400 \mathrm{~mm}$, and it ranges from 80 $105 \mathrm{~mm}$ for a month [4]. In addition, the difference in the dosage of organic fertilizers in the two MT of groundnut became evident between the rates of $5 \mathrm{t}-10 \mathrm{t}$ manure/ha with a difference in yield of each of $0.500 \mathrm{t}-0.540 \mathrm{t}$ dry seed/ha. The increase in yield for $2 \mathrm{MT}$ was between $0.65-1.28$ x above the control (O1) in MK 1995 and MK 1996, respectively (Table 5).

Table 5. Organic matter management on yield of corn-groundnut sequential cropping two seasons on acid upland soil at Bumi Asih, Tanah Laut Regency, South Kalimantan

\begin{tabular}{|c|c|c|c|c|c|c|}
\hline \multirow{2}{*}{$\begin{array}{c}\text { Treatme } \\
\text { nts* }\end{array}$} & \multicolumn{3}{|c|}{ Corn yield ( t kernel/ha) } & \multicolumn{3}{c|}{ Groundnut yield (t dry pods/ha) } \\
\cline { 2 - 7 } & $1995 \mathrm{WS}$ & $1996 \mathrm{WS}$ & $\begin{array}{c}\text { Delta } \\
\text { Yield }\end{array}$ & $1995 \mathrm{DS}$ & $1996 \mathrm{DS}$ & Delta Yield \\
\hline O1 & $0,790 \mathrm{~d} * *$ & $0,37 \mathrm{c}^{* *}$ & $0,42 \mathrm{tn}$ & $1,50 \mathrm{c}$ & $1,710 \mathrm{a}^{* *}$ & $1,220 \mathrm{a}^{* *}$ \\
\hline O2 & $1,130 \mathrm{~cd}$ & $1,26 \mathrm{~b}$ & $-0,12 \mathrm{tn}$ & $3,010 \mathrm{ab}$ & $3,080 \mathrm{bc}$ & $1,240 \mathrm{a}$ \\
\hline O3 & $1,16 \mathrm{~cd}$ & $0,54 \mathrm{c}$ & $0,62^{* *}$ & $3,310 \mathrm{~b}$ & $2,680 \mathrm{ab}$ & $1,680 \mathrm{~b}$ \\
\hline O4 & $1,56 \mathrm{c}$ & $0.54 \mathrm{c}$ & $1,01^{* *}$ & $4,580 \mathrm{c}$ & $2.280 \mathrm{a}$ & $1,570 \mathrm{ab}$ \\
\hline O5 & $3,47 \mathrm{~b}$ & $1,59 \mathrm{~b}$ & $1,88^{* *}$ & $5,780 \mathrm{~d}$ & $4,100 \mathrm{c}$ & $2,150 \mathrm{c}$ \\
\hline O6 & $4,48 \mathrm{a}$ & $2,36 \mathrm{a}$ & $2,48^{* *}$ & $6,940 \mathrm{e}$ & $3.710 \mathrm{c}$ & $2,590 \mathrm{c}$ \\
\hline Avr & 2,16 & 1,11 & 1,05 & 4,400 & 2,920 & 1,740 \\
\hline
\end{tabular}

*) Same as Table $1 .^{+)}$Vegetative phase ${ }^{++}$Harvest phase..**) Values followed by same note no different by DMRT, 05 .

Sources : $[14 ; 15]$

\section{Conclusion}

Organic matter management improves the physical and chemical properties of acid dry soil. It reduces the hardness in the processing layer $(0-15 \mathrm{~cm})$ from $6.0 \mathrm{~kg} / \mathrm{cm}-2$ to $4.0 \mathrm{~kg} / \mathrm{cm}-2$, where it increases below the tillage layer $(10 \mathrm{~kg} / \mathrm{cm}-2)$. The increase of several soil chemical properties such as the $\mathrm{pH}$ and organic C-ranged from $2.10-2.25 \%$. Furthermore, the content of macroelements in corn plants such as $\mathrm{N}, \mathrm{P}, \mathrm{K}, \mathrm{Ca}$, and $\mathrm{Mg}$ was increased at the end of the fourth planting season.

Management of organic matter in dry acid soils at a rate of $20 \mathrm{t} \mathrm{FYM/ha} \mathrm{gave} \mathrm{the} \mathrm{highest}$ yields in the corn-groundnut intercropping pattern. The corn yields were $4.1-5.12$ times above control/farmer practices ( $0.600 \mathrm{t}$ dry shelled/ha). Meanwhile, the groundnut was 0.65 - 1.28 times above the control (1.175 dry seeds/ha).

Acknowledgment. The authors are grateful to the UGM-ACIAR 8904 project for funding the study and the Editors for their valuable input. 


\section{References}

1. Abas Idjudin and S. Marwanto. Journal of Land Resources. Vol 2 (2) : 115 - 125. (2010)

2. Anas, I., M.P., Utami, N. Hakim dan F.Rozie. Peran Pupuk Organik dan Pupuk Hayati dalam Meningkatkan Hasil Padi untuk Swasembada Beras Berkelanjutan (The Role of Organic Fertilizers and Biofertilizers in Increasing Rice Yield for Sustainable Rice Selfsufficiency). inProsceeding of the Semnas Peranan Pupuk NPK dan Pupuk Organik dalam Meningkatkan Produksi Beras Berkelanjutan (National Seminar on the Role of NPK Fertilizers and Organic Fertilizers in Increasing Sustainable Rice Production). Balai Besar Sumberdaya Lahan Pertanian, Bogor. Indonesia (2010)

3. Anny Mulyani,. A.Rachman dan A.Dairah, (2004). Journal of agricultural developed Land Management.Soil Center Research and Development Vol 3 (2004)

4. Beet, W.C. Mutipple Cropping and Tropical Farming Systems.(Grower House, Craft Road, Hamspire, 1982)

5. Dinas Pertanian TPH Kalimantan Selatan, Laporan Tahunan, (Dinas Pertanian Tan Pangan dan Hortikultura, Propinsi Kalimantan Selatan. Banjarbaru, 2010)

6. Ishak J and J. Purwani (2014). Pengaruh Pengelolaan Bahan Organik pada Lahan Kering Masam terhadap Sifat dan Produktivitas Kedelai(Effect of Organic Matter Management on Acid Dry Land on Soybean Properties and Productivity)in Proceeding of Seminar Nasional Hasil Penelitian Tanaman Aneka Kacang dan Ubi-ubian (National Seminar on Research Results of Various Nuts and Sweet Potatoes). Puslitbangtan Bogor. Indonesia, (2014)

7. Kasno, A, Jurnal Tanah dan Sumberdaya Lahan. Vol 13 (1) (2019)

8. Kisman, T ., B. Siswanta \& A. Suntari.Jurnal Tanah dan Sumberdaya Lahan ,Vol 2 (1) (2015)

9. Las, I. dan D. Setyorini, Kondisi Lahan, Teknologi, Arah dan Pengembangan Pupuk Majemuk NPK dan Pupuk Organik (Land Condition, Technology, Direction and Development of NPK Compound Fertilizer and Organic Fertilizer). in proceeding of Semnas Peranan Pupuk NPK dan Pupuk Organik dalam Meningkatkan Produksi dan Swasembada beras berkelanjutan (National Seminar on the Role of NPK Fertilizers and Organic Fertilizers in Increasing Sustainable Rice Production). Balai Besar Sumberdaya Lahan Pertanian Feb. 2010, Bogor. Indonesia (2010)

10. Neneng, L,N., Ai Dariah \& S. Sutono, Jurnal Tanah dan Iklim Vol 39 (2) (2015)

11. Sonia T., E. Handaryanto \& B. Siswanto, Jurnal Tanah dan Sumberdaya Daya Lahan. Vol I (1) (2015)

12. Subagyo,H., N. Suharta dan A.B. Siswanto, Sumberdaya Lahan Indonesia dan Pengelolaannya (Indonesia's Land Resources and Management). (Puslittanak, BogorIndonesia, 2000)

13. Subowo, G, Jurnal Sumberdaya Lahan Vol 4 (1) (2010)

14. Sutanto,R., Supriyo, A., Maas, A, Masyhuri., Radjaguguk, B and S. Hartadi,. The management of upland acid soils for sustainable crop production in South Kalimantan Indonesia.In:Report and Papers on the management of acid soils(IBSRAM/ASIALAND), Meyer, R et al(Eds) p:25-42. Network Document No 11. Bangkok. IBSRAM.(1995)

15. Sutanto,R., Supriyo, A., Maas, A, Masyhuri., Radjaguguk, B and S. Hartadi. The management of upland acid soils for sustainable crop production in South Kalimantan Indonesia. In : Report and Papers on the management of acid soils. (IBSRAM/ASIALAND)Meyer R et al., (Eds) ,p : 31 - 53. Network Document No 12. Bangkok. IBSRAM.(1996)

16. Yusnain, M.A, S. Arif, J. Lumbanraja, S.G. Nugroho dan M. Monaha, Pengaruh jangka panjang pemeberian pupuk organik dan anorganik terhadap perbaikan kualitas tanah 
masam di Taman Bogo (The long-term effect of organic and inorganic fertilizer application on the improvement of acid soil quality in Bogo Park). inproceeding of Semnas Pendayagunaan Tanah Masam (National Seminar on Acidic Soil Utilization), Puslitbang Tanah dan Agroklimat. Bogor-Indonesia, (2004) 